\title{
A study on consumer awareness on consumer rights and responsibilities: A special reference to the rural women of Assam
}

\author{
Manorama Devi and Mira Kalita
}

Received: 01.01.2020; Revised: 01.03.2020; Accepted: 15.04.2020

See end of the paper for authors' affiliations

\section{Manorama Devi}

Department of Family Resource Management and Consumer Science, Assam Agricultural University, Jorhat (Assam) India Email : manoramaaau@gmail. com
Received: 01.01 .2020 , Revised: 01.03 .2020 , Accepted: 15.04 iggest rural consumer markets in the world. Indian market ABSTRACT : India is one of the biggest rural consumer markets in the world. Indian market
have been witnessing several changes following on towards globalization, liberalization and privatization and a large scale entry of multinational company is a major outcomes of new economic order. In the words of Mahatma Gandhi (1890) "A consumer is the most important visitor on our premises; he is not dependent on us. We are dependent on him, he makes favor to us, not we favor on him". This quote expresses the importance of a consumer in the business context. The Consumer Protection Act 1986 provides certain rights to consumers to protect themselves from unfair trade practices resorted by the seller. These rights are well defined by the Consumer Protection Act and there are agencies like the government, consumer courts and voluntary consumer organizations that work towards safe guarding the consumer rights. Each and every consumer should be aware of the consumer rights and responsibilities. For the existing study an attempt was made to find out the awareness level among the rural women. Three villages have been selected randomly from Jorhat sub-division following stratified random sampling method. A total of 120 respondents have been selected for the present study and interview method has been used to collect the data. The result of the study exposes various liabilities of the consumers and it has presented a clear scenario of the consumer's awareness regarding their rights and responsibilities so as to know their demand. The findings of the study revealed that the age is negatively correlated with the awareness level for consumer rights and education and income are positively correlated with the awareness regarding rights of consumer. Majority of the respondents $(60.83 \%)$ showed average awareness towards consumer responsibilities.

KEY WORDS: Consumer, Consumer right, Consumer responsibility, Awareness, Rural women

- HOW TO CITE THIS PAPER : Devi, Manorama and Kalita, Mira (2020). A study on consumer awareness on consumer rights and responsibilities: A special reference to the rural women of Assam. Asian J. Home Sci., 15 (1) : 1-6, DOI: 10.15740/HAS/AJHS/15.1/1-6. Copyright@ 2020: Hind Agri-Horticultural Society. 